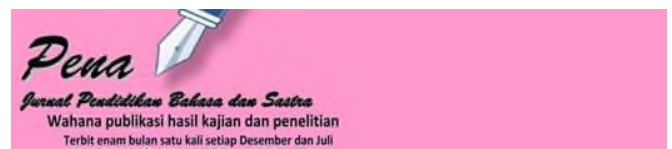

Vol. 7, No.2, Agustus 2018,

P-ISSN: 2089-3973, E-ISSN: 2615-7705

DOI: https://doi.org/10.22437/pena.v7i2.5323

\title{
Penginovasian Bentuk Disfemisme pada Berita Online dan Relevansinya pada Bahan Ajar Bahasa Indonesia di SMP
}

\author{
Nivia Putri Ratna Juwita, Agus Budi Wahyudi \\ Pendidikan Bahasa Indonesia Universitas Muhammadiyah Surakarta \\ nivia_putri@ymail.com, Agus.B.Wahyudi@ums.ac.id
}

\begin{abstract}
Abstrak
Penelitian ini bertujuan untuk mendeskripsikan (1) menemukan bentuk dan fungsi disfemisme pada berita online "detik.com", (2) menginovasikan bentuk disfemisme pada berita online "detik.com", dan (3) mendeskripsikan relevansi penginovasian bentuk disfemisme pada berita online "detik.com" sebagai bahan ajar bahasa Indonesia di SMP. Jenis penelitian yang digunakan dalam penelitian ini adalah penelitian deskriptif kualitatif. Sumber data penelitian ini yaitu berita online detik.com. Data penelitian ini berupa bentuk dan fungsi disfemisme yang terdapat di berita online detik.com. Teknik pengumpulan data menggunakan teknik simak dan catat. Keabsahan data dalam penelitian ini menggunakan triangulasi teori. Penelitian ini menggunakan metode agih dan padan referensial, dengan teknik analisis data menggunakan teknik ganti. Berdasarkan hasil penelitian dari 50 bentuk disfemisme menunjukkan pertama, terdapat tiga bentuk disfemisme yaitu disfemisme bentuk kata, disfemisme bentuk frasa, dan disfemisme bentuk klausa. Kedua, terdapat tujuh fungsi disfemisme, yaitu mengungkapkan keheranan, mengungkapkan keintiman dalam pergaulan, mengungkapkan emosi, mengungkapkan rasa kesal, mengungkapkan penghinaan, mengungkapkan candaan atau tujuan melawak, dan mengungkapkan frustasi dan jengkel.
\end{abstract}

Kata kunci: bentuk, disfemisme, fungsi, penginovasian, relevansi

\begin{abstract}
This study aims to describe (1) find the form and function of dysphemism in online news "detik.com", (2) to innovate the form of dysphemism on online news "detik.com", and (3) to describe the relevance of the innovation of the form of dysphemism on online news " detik.com "as Indonesian language teaching materials in junior high school. The type of research used in this study is descriptive qualitative research. Sources of research data is online news detik.com. This research data in the form and function of dysphemism contained in online news detik.com. Techniques of data collection using techniques refer and note. Validity of data in this study using triangulation theory. This research uses the method of agih and referential padan, with data analysis technique using change technique. Based on the results of the research of 50 forms of dysphemism show first, there are three forms of dysphemism, namely word form dysphemism, phrase form dysphemism, and clauses dysphemism. Secondly, there are seven functions of dysphemism: expressing astonishment, expressing social intimacy, expressing emotions, expressing resentment, expressing contempt, expressing jokes or jesting purposes, and expressing frustration and irritation.
\end{abstract}

Keywords: dysphemism, form, function, innovation, relevance 
Vol. 7, No.2, Agustus 2018,

P-ISSN: 2089-3973, E-ISSN: 2615-7705

DOI: https://doi.org/10.22437/pena.v7i2.5323

\section{PENDAHULUAN}

Media massa yang kini berkembang di lingkungan masyarakat dimanfaatkan sebagai alat yang digunakan untuk menyampaikan berbagai pesan yang dimuat dalam media cetak, media elektronik, dan media online. Berita sudah merambah dalam dunia internet berbasis media online. Tujuan utama media massa yaitu memberikan kemudahan bagi masyarakat untuk mendapatkan berbagai informasi terkini yang dimuat dalam berita.

Berdasarkan data statistik hasil survey Asosiasi Penyelenggara Jasa Internet Indonesia (APJII) tahun 2017, pertumbuhan pengguna internet tahun 2017 mencapai 143,26 juta. Peningkatan kualitas berita merupakan suatu hal penting yang menjadi persaingan antar percetakan dalam mencari pembaca. Tidak menutup kemungkinan dalam meningkatkan daya tarik baca dijumpai pemakaian bahasa yang tidak sopan yang mengandung disfemisme.

Chaer dan Agustina (2004:2-3) menyatakan bahwa sosiolinguistik sebagai bidang ilmu antardisiplin yang tidak hanya mempelajari bahasa dalam bidang kajiannya, namun mempelajari penggunaan bahasa di dalam masyarakat pengguna bahasa. Bahasa sebagai objek kajian sosiolinguistik dilihat serta didekati sebagai sarana interaksi atau komunikasi di dalam masyarakat.

Sumadiria (2005:65) berita mencakup laporan yang disajikan secara cepat mengenai ide atau fakta terbaru yang benar, penting, dan menarik bagi sebagian besar khalayak, melalui media berkala seperti surat kabar, televisi, radio, maupun media online internet. Tujuan utama berita untuk menginformasikan peristiwa yang dianggap penting sebagai upaya untuk memberikan daya tarik supaya orang mau membaca, mendengar, dan menonton sajian berita (Muda, 2005:22).

Kurniawati (2011:51-53) menyatakan bahwa disfemisme sebagai ungkapan yang bias, menyinggung atau melukai. Wijana dan Rohmadi (2006:109-125) menyebutkan ada beberapa bentuk makian dalam dalam bahasa Indonesia, yaitu (a) makian berbentuk kata, (b) makian berbentuk frasa, dan (c) makian berbentuk klausa.

Refmiyanti (2012) menemukan fungsi bahasa sebagai ungkapan makian dalam bahasa Minangkabau di Kenagarian Taluk Kecamatan Lintau Buo Kabupaten Tanah Datar. Fungsi 


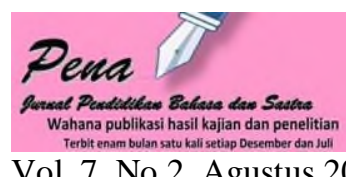

Vol. 7, No.2, Agustus 2018,

P-ISSN: 2089-3973, E-ISSN: 2615-7705

DOI: https://doi.org/10.22437/pena.v7i2.5323

ungkapan makian dalam bahasa tersebut, yaitu: (a) mengungkapan keheranan, (b) mengungkapkan keintiman dalam pergaul, (c) mengungkapkan emosi, (d) mengungkapkan rasa kesal, (e) mengungkapkan penghinaan, (f) mengungkapkan candaan atau tujuan melawak, (g) mengungkapkan frustasi dan jengkel, dan (h) mengungkapkan ancaman. Nilai rasa disfemisme di surat kabar Joglo Semar (Khasan, dkk., 2014:11) meliputi rasa (a) mengerikan, (b) menyeramkan, (c) menguatkan, (d) menjijikkan, (e) porno atau vulgar, dan (f) tidak sopan.

Penginovasian bentuk disfemisme dapat dilakukan dengan cara menginovasikan bentuk disfemisme menjadi ungkapan yang santun. Penginovasian juga dilakukan oleh Wahyudi (2016) dengan judul penelitian "Pengkreasian Stiker Vulgar sebagai Tindakan Bermoral". Wahyudi menggunakan kata penginovasian dengan kata pengkreasian. Hasil dari penelitian ini adalah stiker vulgar banyak digunakan oleh anak didik SMA Muhammadiyah Surakarta, hal tersebut berpotensi mempengaruhi moral anak didik. Stiker vulgar dapat dikreasikan menjadi stiker bijak. Hasil pengkreasian stiker vulgar dapat dimanfaatkan oleh kepala sekolah, wakil kepala sekolah, guru, guru bimbingan konseling, dan masyarakat menjadi pihak yang terlibat dalam penyosialisasian stiker bijak ini. Selaras dengan penelitian Wahyudi, pada penelitian ini menemukan bentuk dan fungsi disfemisme untuk selanjutkan hasil penginovasian disfemisme dapat direlevansikan dengan bahan ajar bahasa Indonesia SMP kelas VIII.

\section{METODE}

Jenis Penelitian

Jenis penelitian yang digunakan dalam penelitian ini adalah penelitian deskriptif kualitatif dengan pendekatan analisis isi atau dokumen. Waktu dalam penelitian ini dilakukan selama 4 bulan. 
Vol. 7, No.2, Agustus 2018,

P-ISSN: 2089-3973, E-ISSN: 2615-7705

DOI: https://doi.org/10.22437/pena.v7i2.5323

Tabel 1. Waktu dan Jenis Kegiatan

\begin{tabular}{|c|c|c|c|c|c|c|c|c|c|c|c|c|c|c|c|c|c|}
\hline \multirow[t]{4}{*}{ No. } & \multirow[t]{4}{*}{ Kegiatan } & \multicolumn{16}{|c|}{ Bulan ke- } \\
\hline & & \multicolumn{4}{|c|}{1} & & & & & \multicolumn{4}{|c|}{3} & \multicolumn{4}{|c|}{4} \\
\hline & & \multicolumn{16}{|c|}{ Minggu ke- } \\
\hline & & 1 & 2 & 3 & 4 & 1 & 2 & 3 & 4 & 1 & 2 & 3 & 4 & 1 & 2 & 3 & 4 \\
\hline 1. & $\begin{array}{l}\text { Penyusunan } \\
\text { Proposal }\end{array}$ & & & & & & & & & & & & & & & & \\
\hline 2. & $\begin{array}{l}\text { Persiapan } \\
\text { penelitian }\end{array}$ & & & & & & & & & & & & & & & & \\
\hline 3. & Pengumpulan data & & & & & & & & & & & & & & & & \\
\hline 4. & Analisis data & & & & & & & & & & & & & & & & \\
\hline
\end{tabular}

Data yang terkumpul berupa bentuk dan fungsi disfemisme yang terdapat di berita online detik.com yang dianggap sebagai bentuk pengasaran. Sumber data yang digunakan dalam penelitian ini dokumen, yaitu berita online detik.com. Narasumber yang dimaksud diperoleh melalui jurnal ilmiah dan teks-teks lain yang relevan dengan sumber data yang hendak diteliti dalam penelitian ini. Teknik pengumpulan data yang digunakan dalam penelitian ini adalah teknik simak dan catat dengan mengumpulkan data bentuk-bentuk disfemisme dalam berita online detik.com, serta teknik studi pustaka yang digunakan untuk menunjang dalam penelitian ini. Keabsahan data dalam penelitian ini menggunakan triangulasi teori. Peneliti memeriksa keabsahan data menggunakan berbagai cara pandang untuk menginterpretasikan data. Penelitian ini menggunakan metode agih dan padan referensial yang alat penentunya merupakan bagian dari bahasa yang bersangkutan.

\section{HASIL DAN PEMBAHASAN}

Secara keseluruhan bentuk disfemisme pada berita online detik.com sebagian besar sama seperti yang telah diapaparkan oleh Wijana dan Rohmadi (2006:109-125), sedangkan fungsi disfemisme seperti yang dikemukakan oleh Refmiyanti (2012).

\section{Bentuk dan Fungsi Disfemisme pada Berita Online detik.com}

\subsection{Bentuk Kata dan Fungsi Disfemisme}

Disfemisme bentuk kata merupakan satuan gramatikal terkecil yang bebas dan memiliki makna dapat berupa kata dasar, kata berimbuhan, dan kata majemuk (Kurniawati, 2011:56). 
Vol. 7, No.2, Agustus 2018,

P-ISSN: 2089-3973, E-ISSN: 2615-7705

DOI: https://doi.org/10.22437/pena.v7i2.5323

(1) Motor Honda Verza bernopol N 3677 WW miliknya digondol M Rizal, pria yang baru dikenalnya. (detik.com/22-01-2018)

Bentuk disfemisme yang terdapat pada berita online detik.com dengan judul Ajak Ngopi dan Belikan Rokok, ini Modus Remaja Sebelum Embat Motor. Berita membahas aksi M. Rizal Urusul (18) warga Pasuruan yang nekat membawa kabur motor milik Khasbiantoro yang baru dikenalnya. Modus yang dilakukan oleh Rizal, merupakan modus baru. Sebelum membawa kabur motor milik korban, ia terlebih dahulu mengajak ngopi dan membelikan rokok untuk korban.

Data (1) terdapat kata digondol merupakan disfemisme bentuk kata berimbuhan. Gondol artinya dibawa dengan mulut (Kamus Besar Bahasa Indonesia, 2012:458). Hal tersebut untuk menyatakan sesuatu yang dibawa oleh hewan, misal ayam goreng di atas meja tadi digondol kucing. Pemilihan kata digondol dimaksudkan untuk mempertegas makna suatu barang yang dibawa tanpa izin, dalam hal ini redaktur memilih kata digondol dalam kalimat Motor Honda Verza bernopol N 3677 WW miliknya digondol M Rizal, pria yang baru dikenalnya untuk memberikan penekanan makna bahwa Rizal membawa kabur motor korban tanpa meminta izin terlebih dahulu dan hal tersebut dikatakan sebagai tindakan pencurian. Berdasarkan konteks berita, kata ini berfungsi untuk mengungkapkan rasa kesal. Berdasarkan KBBI (2012) kesal memiliki arti mendongkol, sebal,kecewa, tidak suka lagi, dan jemu. Data (1) dapat diinovasikan menjadi ungkapan halus atau eufemisme.

(1a) M Rizal mencuri motor honda Verza bernopol N 3677 WW milik korban tanpa meminta izin terlebih dahulu.

(1b) M Rizal membawa kabur motor honda Verza bernopol N 3677 WW milik korban tanpa meminta izin terlebih dahulu.

\subsection{Bentuk Frasa dan Fungsi Disfemisme}

Frasa merupakan kelompok kata yang terdiri dari dua kata atau lebih yang memiliki satu inti. Frasa tidak bermakna proposisi dan tidak memiliki fungsi predikat, serta tidak memiliki kata kerja finit (Kurniawati, 2011:56).

(2) Pengacara Novanto, Firman Wijaya, menyebut pasti Novanto akan membeberkan pelaku kelas kakap itu. (detik.com/11-01-2018) 
Vol. 7, No.2, Agustus 2018,

P-ISSN: 2089-3973, E-ISSN: 2615-7705

DOI: https://doi.org/10.22437/pena.v7i2.5323

Bentuk disfemisme yang terdapat pada berita onlinedetik.com dengan judul Novanto Ingin Jadi Justice Callaborator, Siapa Ikut Diseret? Berita membahas pengajuan diri Novanto sebagai justice collaborator atau sebagai saksi pelaku dalam kasus e-KTP.

Data (2) terdapat frasa kelas kakap yang menunjukkan adanya disfemisme bentuk frasa. KBBI (2012:652), kelas kakap miliki arti kelompok besar (berharga, berkuasa). Berdasarkan konteks berita (2) frasa kelas kakap digunakan untuk menunjuk pelaku yang memiliki kelompok yang besar dan berkuasa atas kasus korupsi e-KTP. Frasa (2) dikatakan disfemisme karena kelas kakap menunjuk pada suatu tindakan yang tidak baik untuk dilakukan oleh pelaku yang merupakan tokoh pemimpin rakyat yang semestinya tidak melakukan tindakan tersebut sebagai contoh kepada masyarakat, frasa ini memiliki nilai rasa menguatkan. Frasa kelas kakap digunakan sebagai fungsi untuk mengungkapkan penghinaan. Data (2) dapat diinovasikan menjadi ungkapan halus atau eufemisme.

(2a) Pengacara Novanto, Firman Wijaya, menyebut pasti Novanto akan membeberkan pelaku yang sudah profesional itu.

\subsection{Bentuk Klausa dan Fungsi Disfemisme}

Klausa merupakan satuan gramatikal yang terdiri dari kelompok kata, sekurangkurangnya terdiri dari subjek dan predikat serta berpotensi menadi sebuat kalimat (Anggraeni, 2015).

(3) Apalagi, saat ini merupakan tenggat terakhir penentuan pengusungan calon gubernur. Partai Gerindra sendiri merasa lebih dekat dengan PKB karena sama-sama berkoalisi di Pilgub Jawa Tengah. (detik.com/10-01-2018)

Bentuk disfemisme yang terdapat pada berita onlinedetik.comdengan judul Gerindra Gagal Bendung All Jokowi Final di Jawa Timur. Berita politik yang membahas pemilihan calon Gubernur Jawa Timur. Koalisi tiga partai politik, Gerindra, PAN, dan PKS yang tidak memiliki calon untuk mendapatkan suara unggul yang dapat mengalahkan suara Khalifah Indar Parawansa dan Saifullah Yusuf.

Data (3) terdapat frasa pengusungan calon gubernur menunjukkan disfemisme bentuk frasa. Berdasarkan KBBI (2012:729) pengusungan memiliki arti proses, cara, perbuatan mengusung. Berasal dari kata usung yaitu bawa, angkut. Berdasarkan konteks berita (3) frasa 
Vol. 7, No.2, Agustus 2018,

P-ISSN: 2089-3973, E-ISSN: 2615-7705

DOI: https://doi.org/10.22437/pena.v7i2.5323

pengusungan calon gubernur menunjukkan proses mambawa atau mengangkut calon gubernur. Frasa ini menandakan adanya disfemisme bentuk frasa yang mengandung nilai rasa tidak sopan yang berfungsi untuk mengungkapkan rasa kesal. Calon gubernur hendaknya dihormati sehingga pemilihan kata pengusungan tidak sepantasnya digunakan. Data (3) dapat diinovasikan menjadi ungkapan halus atau eufemisme.

(3a) Apalagi, saat ini merupakan tenggat terakhir penyerahan nama calon gubernur. Partai Gerindra sendiri merasa lebih dekat dengan PKB karena sama-sama berkoalisi di Pilgub Jawa Tengah.

\section{Penginovasian Bentuk Disfemisme pada Berita Online detik.com}

Berkaitan dengan banyaknya penggunaan disfemisme pada berita online detik.com dilakukan penginovasian bentuk dan fungsi disfemisme menjadi ungkapan halus atau eufemisme. Hasil penelitian ini tentang penginovasian bentuk dan fungsi disfemisme pada berita online detik.com dengan menggunakan teknik ganti.

(1) Motor Honda Verza bernopol N 3677 WW miliknya digondol M Rizal, pria yang baru dikenalnya. (detik.com/22-01-2018)

Data (1) dapat diinovasikan menjadi ungkapan halus atau eufemisme.

(1a) M Rizal mencuri motor honda Verza bernopol N 3677 WW milik korban tanpa meminta izin terlebih dahulu.

(1b) M Rizal membawa kabur motor honda Verza bernopol N 3677 WW milik korban tanpa meminta izin terlebih dahulu.

(2) Pengacara Novanto, Firman Wijaya, menyebut pasti Novanto akan membeberkan pelaku kelas kakap itu. (detik.com/11-01-2018)

Data (2) dapat diinovasikan menjadi ungkapan halus atau eufemisme.

(2a) Pengacara Novanto, Firman Wijaya, menyebut pasti Novanto akan membeberkan pelaku yang sudah profesional itu.

(3) Apalagi, saat ini merupakan tenggat terakhir penentuan pengusungan calon gubernur. Partai Gerindra sendiri merasa lebih dekat dengan PKB karena sama-sama berkoalisi di Pilgub Jawa Tengah. (detik.com/10-01-2018)

Data (3) dapat diinovasikan menjadi ungkapan halus atau eufemisme.

(3a) Apalagi, saat ini merupakan tenggat terakhir penyerahan nama calon gubernur. Partai Gerindra sendiri merasa lebih dekat dengan PKB karena sama-sama berkoalisi di Pilgub Jawa Tengah.

\section{Relevansi Penginovasian Bentuk Disfemisme pada Berita Online detik.com}

\subsection{Penginovasian Bentuk Disfemisme pada Berita Online sebagai Bahan Ajar}


Vol. 7, No.2, Agustus 2018,

P-ISSN: 2089-3973, E-ISSN: 2615-7705

DOI: https://doi.org/10.22437/pena.v7i2.5323

Mengenai penggunaan bentuk disfemisme yang terdapat pada berita online detik.com perlu adanya upaya penginovasian. Perlu adanya beberapa upaya yang dilakukan untuk mengurangi penggunaan bentuk disfemisme.

a. Memberikan pemahaman mengenai dampak negatif dari bentuk disfemisme kepada guru dan anak didik, sehingga dapat menghindari penggunaan bentuk disfemisme dalam pembelajaran.

b. Mendiskusikan mengenai penggunaan bentuk disfemisme dalam berita online kepada guru dan anak didik.

c. Menginovasikan bentuk disfemisme menjadi ungkapan yang santun, sehingga dapat digunakan dalam pembelajaran.

Hasil penelitian ini dapat direlevansikan sebagai bahan ajar pembelajaran Bahasa Indonesia di SMP kelas VIII Kurikulum 2013 KD 4.2 menyusun teks cerita moral/ fabel, ulasan, diskusi, cerita prosedur, dan cerita biografi sesuai dengan karakteristik teks yang akan dibuat baik secara lisan maupun tulisan. Pada penelitian ini ditemukan bentuk dan fungsi disfemisme yang terdapat pada teks diskusi yang disusun ke dalam RPP. Hasil penelitian adalah bentuk dan fungsi disfemisme yang telah diinovasikanmenjadi ungkapan yang lebih santun.

\section{PEMBAHASAN}

Berdasarkan hasil penelitian terdapat perbandingan antara penelitian terdahulu yang relevan dengan penelitian ini. Berikut perbandingan antara penelitian terdahulu dengan penelitian ini.

Bakhtiar (2011) meneliti "Assessing the Offensiveness Level of Taboo Words in Persian". Hasil penelitian Sharifi dalam situasi formalitas jenis kelamin, wanita lebih mempertimbangkan penggunaan disfemisme daripada laki-laki. Kata-kata tabu bahasa dianggap ortofemistik oleh laki-laki dan wanita. Tingkat pelanggaran penggunaan tabu bahasa dalam bahasa Persian didominasi oleh laki-laki. Sedangkan, hasil penelitian saya ditemukan tiga bentuk disfemisme dengan menggunakan teori yang dikemukakan oleh Wijana dan Rohmadi (2006:109125). Bentuk-bentuk disfemisme yang ditemukan, yaitu (a) disfemisme bentuk kata, sejumlah 16 wujud kata, (b) disfemisme bentuk frasa sejumlah 18 wujud frasa, dan (c) disfemisme bentuk klausa sejumlah 16 wujud klausa. 
Vol. 7, No.2, Agustus 2018,

P-ISSN: 2089-3973, E-ISSN: 2615-7705

DOI: https://doi.org/10.22437/pena.v7i2.5323

Kurniawati (2011) meneliti "Eufemisme dan Disfemisme dalam Spiegel Online". Hasil dari penelitian tersebut adalah ditinjau dari bentuk satuan gramatikal, disfemisme yang digunakan dalam Spiegel Online berupa satuan gramatikal kata, frasa, dan kalimat. Sedangkan hasil penelitian saya ditemukan tiga bentuk disfemisme dengan menggunakan teori yang dikemukakan oleh Wijana dan Rohmadi (2006:109-125). Bentuk-bentuk disfemisme yang ditemukan, yaitu (a) disfemisme bentuk kata, sejumlah 16 wujud kata, (b) disfemisme bentuk frasa sejumlah 18 wujud frasa, dan (c) disfemisme bentuk klausa sejumlah 16 wujud klausa.

Sharifi (2012) meneliti "Head and Face Parts Naming in Kurdi: Lexical Diversity and Productivity". Hasil penelitian Sharifi adalah pemberian nama bagian wajah manusia terorganisasi dengan baik dalam etnis Kurdi. Wajar dalam penggunaan bahasa ada kata yang dinilai lebih produktif dari kata yang lain. Diketahui bahwa di etnis Kurdi mempunyai banyak kata untuk menyebut penamaan bagian wajah manusia yang dianggap sebagai disfemisme yang tidak memiliki padanan kata yang tepat dalam bahasa Inggris.

Sedangkan, hasil penelitian saya ditemukan tujuh fungsi disfemisme dengan menggunakan teori Refmiyanti (2012). Hasil temuan bentuk disfemisme terdiri dari tiga bentuk, yaitu (a) disfemisme bentuk kata, sejumlah 16 wujud kata dengan rincian berfungsi untuk mengungkapkan keheranan 1 wujud kata, mengungkapkan keintiman dalam pergaulan 1 wujud kata, mengungkapkan emosi 5 wujud kata, mengungkapkan rasa kesal 5 wujud kata, mengungkapkan penghinaan 2 wujud kata, mengungkapkan candaan atau tujuan melawak 1 wujud kata, dan mengungkapkan frustasi dan jengkel 1 wujud kata. (b) Disfemisme bentuk frasa, sejumlah 18 wujud frasa dengan rincian berfungsi untuk mengungkapkan emosi 4 wujud frasa, mengungkapkan rasa kesal 7 wujud frasa, mengungkapkan penghinaan 5 wujud frasa, dan mengungkapkan frustasi dan jengkel 2 wujud frasa. (c) Disfemisme bentuk klausa, sejumlah 16 wujud klausa dengan rincian mengungkapkan keheranan 1 wujud klausa, mengungkapkan keintiman dalam pergaulan 3 wujud klausa, mengungkapkan emosi 6 wujud klausa, mengungkapkan rasa kesal 3 wujud klausa, mengungkapkan penghinaan 2 wujud klausa, mengungkapkan candaan atau tujuan melawak 1 wujud klausa, dan mengungkapkan frustasi dan jengkel 1 wujud klausa. 
Vol. 7, No.2, Agustus 2018,

P-ISSN: 2089-3973, E-ISSN: 2615-7705

DOI: https://doi.org/10.22437/pena.v7i2.5323

Pilotti, et al. (2012) meneliti "Taboo Words in Expressive Language: Do Sex and Primary Language Matter?" Hasil penelitian menunjukkan bahwa responden menyatakan bahwa katakata tabu bahasa Spanyol lebih banyak digunakan oleh pria daripada wanita. Memang penyimpangan dalam bahasa Spanyol lebih banyak digunakan oleh pria, namun dalam bahasa Inggris penyimpangan banyak digunakan oleh pria maupun wanita. Sedangkan, hasil penelitian saya ditemukan tujuh fungsi disfemisme dengan menggunakan teori Refmiyanti (2012), yaitu (a) mengungkapkan keheranan, (b) mengungkapkan keintiman dalam pergaulan, (c) mengungkapkan emosi, (d) mengungkapkan rasa kesal, (e) mengungkapkan penghinaan, (f) mengungkapkan candaan atau tujuan melawak, dan (g) mengungkapkan frustasi dan jengkel.

Anggraeni (2015) meneliti "Eufemisme dan Disfemisme dalam Talk Show Mata Najwa di Metro TV (Kajian Sosiolinguistik)", membahas eufemisme dan disfemisme dalam Talk Show Mata Najwa. Penelitian ini menghasilkan tiga bentuk satuan gramatikal ungkapan eufemisme dan ungkapan disfemisme, referensi ungkapan eufemisme dan disfemisme, fungsi dan makna ungkapan eufemisme dan disfemisme. Adapun hasil penelitian saya ditemukan tiga bentuk disfemisme dengan menggunakan teori yang dikemukakan oleh Wijana dan Rohmadi (2006:109125), dan ditemukan tujuh fungsi disfemisme dengan menggunakan teori Refmiyanti (2012).

Affini (2017) meneliti “Analisis Kata Tabu dan Klasifikasinya di Lirik Lagu Eminem pada Album The Marshal Mathers LP". Hasil dari penelitian ini adalah lagu berjudul "KIM" dari ketiga lagu yang terdapat dalam album The Marshal Mathers LP menunjukkan hasil analisis lagu yang paling ekstrim dalam pengungkapan kata tabu secara vulgar dan bebas. Sedangkan, hasil penelitian saya ditemukan tujuh fungsi disfemisme dengan menggunakan teori Refmiyanti (2012), yaitu (a) mengungkapkan keheranan, (b) mengungkapkan keintiman dalam pergaulan, (c) mengungkapkan emosi, (d) mengungkapkan rasa kesal, (e) mengungkapkan penghinaan, (f) mengungkapkan candaan atau tujuan melawak, dan (g) mengungkapkan frustasi dan jengkel.

Eliya (2017) meneliti "Eufemisme dan Disfemisme dalam Catatan Najwa 'Darah Muda Daerah': Pola, Bentuk, dan Makna". Hasil penelitian ini adalah terdapat empat bentuk disfemisme, yaitu kategori makna yang berupa kata, frasa, dan klausa dalam bentuk tiga ekspresi figuratif. Sedangkan hasil penelitian saya ditemukan tiga bentuk disfemisme dengan 


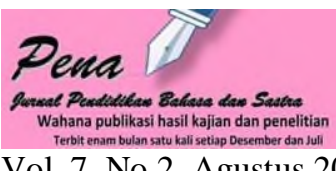

Vol. 7, No.2, Agustus 2018,

P-ISSN: 2089-3973, E-ISSN: 2615-7705

DOI: https://doi.org/10.22437/pena.v7i2.5323

menggunakan teori yang dikemukakan oleh Wijana dan Rohmadi (2006:109-125). Bentukbentuk disfemisme yang ditemukan, yaitu (a) disfemisme bentuk kata, sejumlah 16 wujud kata, (b) disfemisme bentuk frasa sejumlah 18 wujud frasa, dan (c) disfemisme bentuk klausa sejumlah 16 wujud klausa.

\section{SIMPULAN}

Berdasarkan hasil penelitian menunjukkan bahwa Pertama, terdapat tiga bentuk disfemisme pada berita online detik.com yaitu (a) disfemisme, (b) disfemisme bentuk frasa, dan (c) disfemisme bentuk klausa. Tujuh fungsi disfemisme pada berita online detik.com yaitu (a) mengungkapkan keheranan, (b) mengungkapkan keintiman dalam pergaulan, (c) mengungkapkan emosi, (d) mengungkapkan rasa kesal, (e) mengungkapkan penghinaan, (f) mengungkapkan candaan atau tujuan melawak, dan (g) mengungkapkan frustasi dan jengkel. Kedua, penelitian ini tentang penginovasian bentuk dan fungsi disfemisme pada berita online detik.com dengan menggunakan teknik ganti sebagai wujud tindakan santun dalam bermedia. Ketiga penginovasian bentuk disfemisme dalam berita online detik.com dimanfaatkan sebagai pengembang bahan ajar dalam pembelajaran bahasa Indonesia SMP kelas VIII berdasarkan kurikulum 2013 KD 4.2 menyusun teks diskusisesuai dengan karakteristik teks yang akan dibuat baik secara lisan maupun tulisan.

\section{SARAN}

\section{Bagi Dunia Pendidikan}

Bahasa yang memiliki nilai rasa tidak sopan tidak boleh digunakan oleh guru dan siswa dalam berkomunikasi. Melalui pemahaman bahasa disfemisme, siswa dan guru dapat menggunakan bahasa yang baik dalam pembelajaran.

\section{Bagi Peneliti Lain}

Penelitian ini menjadi masukan dan memberikan kebendaharaan ilmu tentang bahasa, bahwa disfemisme masih banyak digunakan oleh media untuk tujuan tertentu.

\section{Bagi Media Massa}




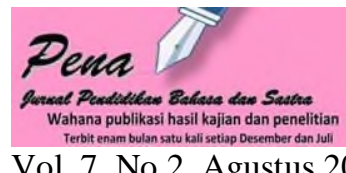

Vol. 7, No.2, Agustus 2018,

P-ISSN: 2089-3973, E-ISSN: 2615-7705

DOI: https://doi.org/10.22437/pena.v7i2.5323

Penggunaan bentuk dan fungsi disfemisme yang ditemukan dalam penelitian ini sebagai bahan acuan bagi media massa untuk lebih memilih kosakata yang sesuai dan tidak terlalu bernilai kasar.

\section{DAFTAR PUSTAKA}

Affini, Laily Nur. 2017. "Analisis Kata Tabu dan Klasifikasinya di Lirik Lagu Eminem pada Album The Marshal Mathers LP”. Lensa: Kajian Kebahasaan, Kesusastraan, dan Budaya, 07 (01): 93-113.

Anggraeni, Dian Wibi. 2015. "Eufemisme dan Disfemisme dalam Talk Show Mata Najwa di Metro TV (Kajian Sosiolinguistik)”. Tesis. Surakarta: Fakultas Pascasarjana, Universitas Sebelas Maret.

Asosiasi Penyelenggara Jasa Internet Indonesia (APJII). 2017. "Infografis Penetrasi \& Perilaku Pengguna Internet Indonesia 2017'. Jakarta: APJII. Diakses pada 18 April 2018 (https://apjii/or.id/survei2017/).

Badan Pengembangan dan Pembinaan Bahasa. 2012. Kamus Besar Bahasa Indonesia Edisi Keempat. Jakarta: Badan Pengembangan dan Pembinaan Bahasa, Kementrian Pendidikan dan Kebudayaan Republik Indonesia.

Bakhtiar, Mohsen. 2011. "Assessing the Offensiveness Level of Taboo Words in Persian". The Journal of International Social Research, 04 (19): 15-23.

Chaer, Abdul dan Leonie Agustina. 2004. Sosiolinguistik Perkenalan Awal. Jakarta: PT Rineka Cipta.

Eliya, Ixsir. 2017. "Eufemisme dan Disfemisme dalam Catatan Najwa 'Darah Muda Daerah': Pola, Bentuk, dan Makna". Deiksis: Jurnal Pendidikan Bahasa dan Sastra Indonesia, 04 (02): 22-30.

Khasan, Auriga Maulana, Sumarwati dan Budhi Setiawan. 2014. "Pemakaian Disfemisme dalam Berita Utama Surat Kabar Joglosemar." Basastra Jurnal Penelitian Bahasa, Sastra Indonesia dan Pengajarannya, 02 (03): 1-12.

Kurniawati, Heti. 2011. "Eufemisme dalam Spiegel Online”. Litera, 10 (01): 51-63.

Muda, Deddy Iskandar. 2005. Jurnalistik Televisi Menjadi Reporter Profesional. Bandung: PT Remaja Rosdakarya.

Pilotti, Maura, et al. 2012. "Taboo Words in Expressive Language: Do Sex and Primary Language Matter". American International journal of Contemporary Research, 02 (02): 17-26. 


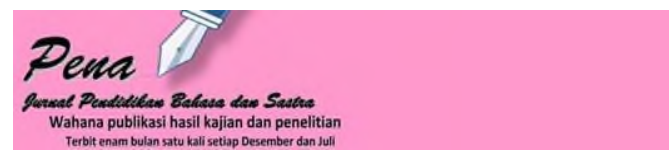

Vol. 7, No.2, Agustus 2018,

P-ISSN: 2089-3973, E-ISSN: 2615-7705

DOI: https://doi.org/10.22437/pena.v7i2.5323

Refmiyanti, Agustina, dan Erizal Gani. 2012. "Ungkapan Makian Bahasa Minangkabau di Kenagarian TalukKecamatan Lintau Buo Kabupaten Tanah Datar”. Jurnal Pendidikan Bahasa dan Sastra Indonesia, 1 (1): 381-389.

Sharifi, Shahla. 2012. "Head and Face Parts Naming in Kurdish: Lexical Diversity and Productivity”. Internasional Journal of Linguistics, 04 (03): 523-535.

Sumadiria, AS. Haris. 2005. Jurnalistik Indonesia Menulis Berita dan Feature Panduan Praktis Jurnalis Profesional. Bandung: Simbiosa Rekatama Media.

Wahyudi, Agus Budi. 2016. "Pengkreasian Stiker Vulgar sebagai Tindakan Bermoral". Bahastra, XXXVI (01): 1-22.

Wijana, I Dewa Putu dan Muhammad Rohmadi. 2006. Sosiolinguistik Kajian Teori dan Analisis. Yogyakarta: Pustaka Pelajar. 